\title{
Research and Practice of the Teaching Mode of "Class, Post and Certificate Deep Integration"
}

\author{
ZhangNa $^{1}$, WanBoqin ${ }^{2}$ \\ ${ }^{1}$ TianJin college, University of Science\&Technology Beijing, North Ring Road, BaoDi, China \\ ${ }^{2}$ TianJin college, University of Science \&Technology Beijing, North Ring Road, BaoDi, China
}

Keywords: class-post--certificate integration, talent training

Abstract: In 2014, the Chinese Ministry of Education proposed to strengthen the cultivation of applied talents. In response to the call, we explored how to implement the teaching mode of "class, post and certificate deep integration". Based on the research of market demand and student characteristics, we screened the group of jobs suitable for our students. Then we designed a curriculum system consistent with market demand and the professional certificates. Ultimately it realizes the unification of class, post and certificate.

\section{The Meaning of "Class, Post and Certificate Integration"}

In the concept of "class, post, and certificate integration", "class" refers to professional courses, "post" refers to professional positions, and "certificate" refers to professional research. "Class, post, and certificate integration" means that the professional training objectives and professional job requirements are unified, and the teaching content and professional qualification standards ("certificate") are docking. ${ }^{[1]}$

\section{Financial Talent Demand Analysis}

To determine the professional courses and curriculum standards to be established, from April 2017 to September 2018, we conducted an investigation of the talent market. The research sites include banks, securities companies, on-site job fairs, YingJieSheng network, ZhiLian recruitment, schools.

\subsection{Characteristics of Financial Talent Demand}

In the survey, we found that the current demand for financial talents presents the following characteristics:

\subsubsection{Talent Demand Presents a Pyramid Structure}

At present, the market has little demand for senior financial talents. However, the demand for front-line service personnel and business operational talents is far greater than the former. 


\subsubsection{Grassroots Posts Emphasize Knowledge Breadth and Practical Ability}

Lobby manager, marketing and other grassroots jobs, require practitioners to master the basic concepts of professionalism. But the practitioners should have a wide range of knowledge and strong practical ability. It is best to have a corresponding certificate of practice.

\subsubsection{Future Talent Demand Will Tend to be International and Complex}

With the financial industry opening to the outside world, the market will have great demand for financial talents with international vision, compound talents who are proficient in finance and software, and grassroots compound talents with broad knowledge.

\subsection{Typical Jobs in the Financial Industry}

In the current talent market, there are four main types of typical jobs.

\subsubsection{Banking Post}

The typical posts are: bank teller, lobby manager, account manager, loan examiner, special financing post, investment banking, risk managers.

\subsubsection{Securities and Futures Post}

(1) Securities posts

These positions are mainly concentrated in securities companies. The typical posts are account manager, teller, securities issuer, securities investment advisor, securities analyst, investment banking, and risk manage.

(2) Futures posts

Futures positions are mainly concentrated in futures companies. The typical posts are traders, marketing, market research and development.

(3) Fund positions

These posts are mainly concentrated in fund companies. The typical posts are fund managers, industry researchers, financial engineering analysts, institutional investment managers, traders, marketing posts.

\subsubsection{Insurance Positions}

Insurance positions are mainly concentrated in insurance companies. The typical posts are insurance underwriting \& claims, insurance billing, reinsurance.

\subsubsection{Other Posts}

In addition, financial leasing companies, trust companies, financial asset management companies also provide some posts, but the ratio is very low.

\section{Design Plan of "Class, Post and Certificate Integration" Course System}

\subsection{Post Group Screening}

Combined with market demands and student characteristics, we have selected the jobs in the financial industry, and taken it as the focus of professional talent training. The positions we choose mainly have the following categories: 
(1) Integrated tellers; (2) Loan officers\& loan examiners; (3) Consulting positions (Bank lobby managers/ securities investment advisors/ financial advisors); (4) Marketing positions (Including various account managers).

\subsection{Refining Post Knowledge and Ability}

We conducted an in-depth analysis of each position, and refined the core knowledge and capabilities of each position.

\subsubsection{The Ability and Knowledge of Bank Tellers}

(1) Core competence of the post: Handle counter business\& Counter marketing; Voucher filling \& keeping; Count cash, RMB identification, Keyboard entry.

(2) Knowledge and skill requirements: Banking business\& main products; Financial accounting knowledge; Legal knowledge\& occupational disciplines.

(3) The docking course: Business and management of commercial banks, banking laws and regulations, financial accounting, financial marketing.

(4) The docking certificate: Banking qualification certificate.

\subsubsection{The Ability and Knowledge of Loan Officers}

(1) Core competence of the post: Financial marketing; Interpersonal relationship processing; Familiar with loan business process; Know the law.

(2) Knowledge and skill requirements: Financial marketing; Loan business; occupational disciplines.

(3) The docking course: Banking business\& main products, financial marketing, banking laws and regulations.

(4) The docking certificate: Banking qualification certificate.

\subsubsection{The Ability and Knowledge of Securities Investment Advisors}

(1) Core competence of the post: be able to conduct securities investment analysis; Understand financial marketing; Good communication skills.

(2) Knowledge and skill requirements: Securities investment; Investment risk management; Marketing knowledge; Legal knowledge\& occupational disciplines.

(3) The docking course: Securities investment, financial planning, financial marketing.

(4) The docking certificate: Securities qualification certificate, financial planner certificate.

\subsubsection{The Ability and Knowledge of Financial Advisors}

(1) Core competence of the post: Rich financial, investment, economic, legal knowledge. Familiar with various financial products, and understand securities investment.

(2) Knowledge and skill requirements: Securities investment; Insurance knowledge; Tax knowledge; Legal knowledge\& occupational disciplines.

(3) The docking course: Economics, financial accounting, investment, insurance, taxation, legal knowledge\& professional disciplines.

(4) The docking certificate: Financial planner certificate.

\subsection{Professional Curriculum System Design}

Based on the essential knowledge, skills, professional literacy and professional qualification 
standards for the position, we designed 4 course modules for financial engineering. And we then divided 8 semesters into 3 training stages:

The first stage is to lay the foundation. At this stage, we conduct professional general education for students. By learning courses in economics, finance, law, accounting, financial marketing, students can have a basic understanding of the profession. These courses are mainly offered in the first to third semesters.

The second stage is to cultivate professional literacy. At this stage, we offer four modules of professional courses for students. The first is the bank module, which mainly provides a course for commercial bank management. The second is the securities module, which mainly provides courses in securities investment and securities investment funds. The third is the financial planning module, which mainly provides personal financial management courses. The fourth is the futures and derivatives module, which mainly provides futures and derivatives courses. The above courses are offered in the 4th to 6th semester.

The third stage is the professional practice stage. We introduce comprehensive practical training courses and real projects of cooperative institutions. Based on the actual needs of industry enterprises, we cooperate to develop students' practical ability. Courses offered at this stage include financial English, commercial banking credit business training, securities investment training, personal financial training, professional internships. The above courses are offered in the 7th to 8th semester and summer holidays.

Combining the core competence of the post, we integrate the professional certificate with the professional curriculum. Among them, the bank module course is connected to the junior bank qualification. Securities module is docked to securities qualification examination, fund qualification examination. The wealth management module is connected to the financial planner's secondary examination. ${ }^{[2]}$

\section{Conclusions}

In this paper, we screened the group of jobs suitable for students and designed a curriculum system. Ultimately it realizes the unification of class, post and certificate.

\section{References}

[1] W X Song, K Li, H Duan.(2013) Reform of the Integrated Talents Training Mode of Network Professionals in Higher Vocational Colleges. Computer Era,8,56-60.

[2] X J Min.(2013) Innovation and Design of Higher Vocational Course Model Which is based on Deep Docking of the Course Certificate. Chinese Market, 45,172-174. 